\title{
The Relationship between the Government Expenditures and Revenues in the Long Run a Case Study of Iran
}

\author{
${ }^{1}$ Farshad Sameni Keivani \\ ${ }^{l}$ Department of Accounting, Roudsar and Amlash Branch, Islamic Azad University, Roudsar, Iran
}

\begin{abstract}
This study focuses the relationship between the government revenues and current expenditures in long run in Iran Country covering data 1986 2110. The research uses the annual time series data which is obtained from the website of Central Bank. The OLS method is used to estimate the liner regression to show the relationship between these variables. EVIEWS 8 and SPSS software is applied to do this survey. This paper explains the relationship between government current expenditures and revenues of taxes and oil in the long run. The results of the research state in the long run during the years of the study the coefficients of the oil revenue and the tax revenue are 0.025 and -2.32 respectively. Hence the oil revenue in the long run is one of the main factors to make a decision by the government who determine its current expenditure level. The decision makers in Iran can use the results of this study to make better decisions for its budget planning.

Key words: the tax revenue, the oil revenue and the government expenditures and Iran.
\end{abstract}

\section{Introduction}

To take a good decision and to improve their societies, the governments need to design the budget. To do its functions a government uses budget as a planning and financial tool. There is a budget deficit while the government revenues are less than the government expenditures. Vice versa, when the government expenditures less than its revenues it is said that the government has budget surplus. There are always the budget deficit all of years during all of years of this study. In other words, the budget deficit is a characteristic of Iran economics.

The budget deficit is determined by calculation of the difference between government expenditures and revenues. Some time the governments to reduce the unemployment rate at their societies use the budget deficit policy but having the budget deficit in the long period not only is a policy but also is a problem for society that it needs to solve. To solve this problem the government should reduce its expenditures or it should increase its revenues resources.

The budget revenue resources should be stationary and they must have the lowest fluctuations. Strongly dependent budget with the production of a goods shows the government have to change its expenditures or revenues. To achieve these aims the government should know the relationship between government revenues and expenditures. It has been observed that in some cases revenue increase or expenditures reduction affect on its corresponding variable and makes the adopted policy ineffective. So before to make a decision about reducing of the expenditure or increasing revenues it is important to know the amount of dependences of those variables that affect on the government expenditures.

One of the most important topics which have not been done enough research is the relationship between the government revenues and the expenditures especially in the long run. To obtain the appropriate financial policy to reduce or remove budget deficit it is necessary to find the relationship between government revenues and expenditures. In fact it is very important that the government informs the budget how much is affected from each of the revenues and which one of the revenues is the most effective.

Before any decision on how to reduce or remove the budget deficit the relationship between revenues and expenditure should be estimate. The government expenditures even have increased in some the years its revenues have declined in Iran you can see the following graph:

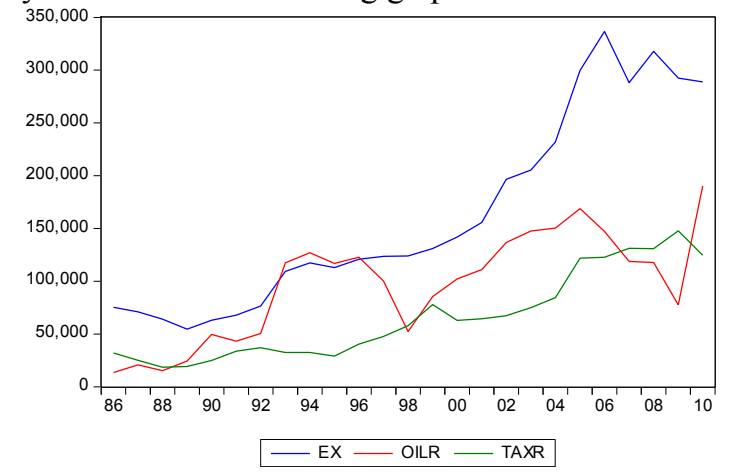


Where

$\mathrm{EX}=$ the government current expenditures in Iran

$\mathrm{TAXR}=$ the tax revenues in Iran

OILR $=$ the oil revenues in Iran

The ratio of the oil revenues to current expenditures has always been too high. Even in the some years it has been about one you can easily in the following diagram:

the Ratio of the Oil Revenue to Expenditures

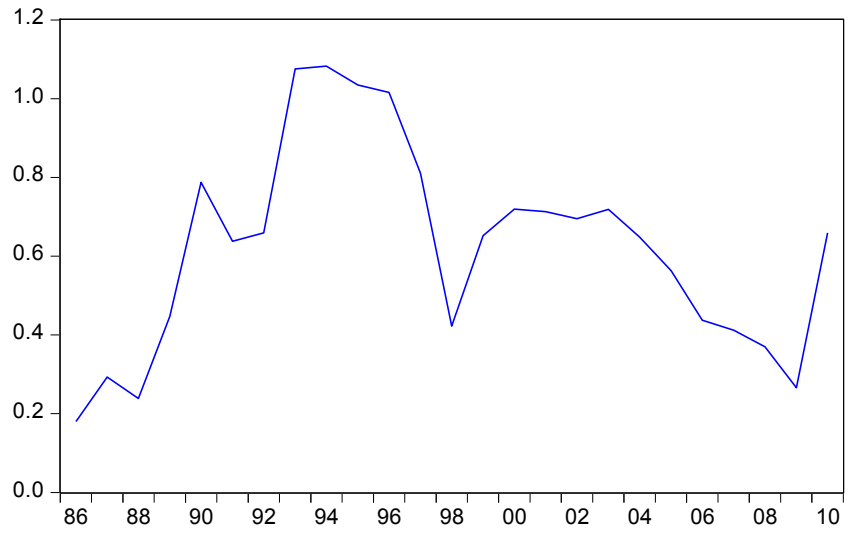

However, the ratio of the tax revenues to the government current expenditures never has been more than 60 percent. You can see this matter at the following graph:

the Ratio of TAXR TO EX

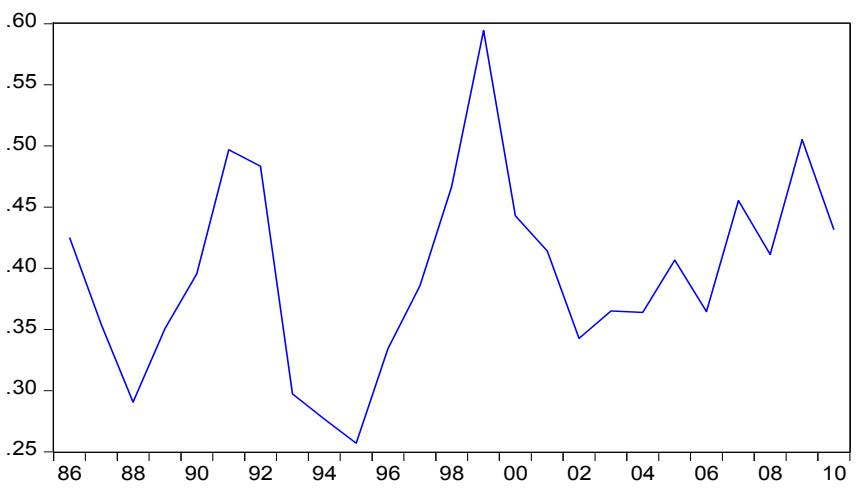

The main objective of this research is to determine the relationship between government revenues and expenditures in order to cope with Iran budget deficit in the long run. Determination of this relationship will help the government make a good decision to reduce or remove the budget deficit.

Over the recent years some studies have been conducted on the effects of budget deficit on Iran economy. For example, Blackley (1986) found that raises in federal tax revenues precede raises in spending, and so may not cause to smaller federal deficits [9] and the other study, in 1986, was shown evidence to support the view that spending rises cause to tax rises at the federal level by Von Furstenberg, Green and Jeong.

Most of these studies have been on the effect of budget deficit on variables like economic growth and inflation; however, no efficient study has been carried out on the relationship between government revenues and expenditures especially on the short run or if any, it was in the past decade. Therefore the study of the causative relationship between the said variables on the basis of the latest data is suggestive of its new dimension; furthermore, since economic conditions of Iran differ from those of most countries of the world in term of institution, structure and organization, the research findings can enrich the literature.

The main questions in this paper are as follow:

1. Is there a significant relationship between the tax revenues and the government current expenditures in Iran on the short run?

2. Is there a significant relationship between the government oil revenues and the government current expenditures in Iran on the short run?

The main hypotheses in this study are as follow:

1. There is a significant relationship between the tax revenues and the government current expenditures in Iran on the short run.

2. There is a significant relationship between the government oil revenues and the government current expenditures in Iran on the short run. 


\section{Materials and Methods}

The study uses the method descriptive and analytical. To achieve the goal theoretical discussions and empirical studies was conducted by library methods. The required data, the related background information on empirical studiers and literature was collected by internet and library methods. The required statistical data was gathered from statistical data of Central Bank of Iran. After collecting the secondary data, it is necessary to determine to be or not to be the stationary for the data. Unit root test of Augmented Dickey-Fuller (ADF) is applied for it. Then is used the linear regression model to estimate the relationship between government revenues and expenditures in Iran. To estimate that model, the survey applies Eiews8 Software. Then significant of the model and coefficients investigates using appropriate statistical analyzes.

The model which is applied in this research as follow:

Where

$$
\mathrm{EX}=\alpha_{1} \mathrm{TAXR}+\alpha_{2} \mathrm{OIL}
$$

$\mathrm{EX}=$ the government current expenditures in Iran

$\mathrm{TAXR}=$ the tax revenues in Iran

OIL $=$ the oil revenues in Iran

Statistical Population limits to Iran economy. The studied variables in this study are annual time series data mainly from 1986 to 2010. To determine whether the variables are long run association or not the study applies the Johansen Cointegration Test.

\section{Results and Discussion}

Fist it is necessary to check the time series data is stationary or not. There are some ways to check it. One way is Unit root test of Augmented Dickey-Fuller (ADF) which is used by this study. In order to the results of the ADF test, at 5\% confidence level, all of the data are not stationary at the level but for the first differencing all of them are stationary for the first differencing. In other words, however the variables have unit root test at the level but have not unit root test while the variables are converted to first difference.

The results are as you can see at the following table:

Table1. The results of ADF test

\begin{tabular}{|c|c|c|c|}
\hline The names of variables & ADF statistics & $\begin{array}{c}\text { The Critical } \\
\text { Value at 5\% }\end{array}$ & The Stationary at \\
\hline EX & -4.371801 & -3.622033 & 1 st difference \\
\hline OIL & -3.943905 & -3.622033 & 1 st difference \\
\hline TAXR & -4.638827 & -3.690814 & 1 st difference \\
\hline
\end{tabular}

The linear regression model is used to describe the relationship between the government revenues and expenditure in the long run. To determine whether the variables are long run association or not the study applies the Johansen Cointegration Test. For this model the results are as follow:

\begin{tabular}{|c|c|c|c|c|}
\hline $\begin{array}{l}\text { Hypothesized } \\
\text { No. of CE(s) }\end{array}$ & Eigenvalue & $\begin{array}{c}\text { Trace } \\
\text { Statistic }\end{array}$ & $\begin{array}{c}0.05 \\
\text { Critical Value }\end{array}$ & Prob.** \\
\hline None * & 0.694114 & 33.70501 & 29.79707 & 0.0169 \\
\hline At most 1 & 0.283797 & 7.645068 & 15.49471 & 0.5041 \\
\hline At most 2 & 0.013618 & 0.301645 & 3.841466 & 0.5829 \\
\hline
\end{tabular}

Trace test indicates 1 cointegrating eqn(s) at the 0.05 level

To compare the Trace Statistic and the Critical Value at 5\%, we can check the variables are co-integrated or not (you can see at the above table). In the first row, none means that is no co-integrated equation or there is no long run association. The P-Value for this hypothesis is 0.0169 or less than $5 \%$ it means we can reject the null hypothesis meaning that we can accept the alternative hypothesis. On the other hand, in the second row of the table, the At most 1 means there is one co-integrated equation. The P-Value for this hypothesis is 0.5041 or more than 5\% it means we can't reject the null hypothesis meaning that we accept the null hypothesis. So there is at most one co-integrated equation it means that the expenditures, tax and oil revenue are co-integrated, it means all three variables have long run association or they move together. Similarly, it will prove by using Maximum Eigenvalue method as you can see the below table: 
Unrestricted Cointegration Rank Test (Maximum Eigenvalue)

\begin{tabular}{|c|c|c|c|c|}
\hline Hypothesized & & Max-Eigen & 0.05 & \\
\hline No. of CE(s) & Eigenvalue & Statistic & Critical Value & Prob. ** \\
\hline None * & 0.694114 & 26.05995 & 21.13162 & 0.0093 \\
\hline At most 1 & 0.283797 & 7.343423 & 14.26460 & 0.4493 \\
\hline At most 2 & 0.013618 & 0.301645 & 3.841466 & 0.5829 \\
\hline
\end{tabular}

Max-eigenvalue test indicates 1 cointegrating eqn(s) at the 0.05 level

The coefficients of the model for long run can found in the following table:

\begin{tabular}{ccc}
1 Cointegrating Equation(s): & Log likelihood \\
\hline \hline Normalized cointegrating coefficients (standard & error in parentheses) \\
EX & TAXR & OILR \\
1.000000 & -2.322529 & 0.024595 \\
& $(0.12743)$ & $(0.11800)$
\end{tabular}

Thus in general, the coefficient of the TAXR is -2.322529 at the long run during the period of 1986-2010 and the coefficient of the OILR is 0.024595 at the long run during. Hence the oil revenue in the long run is one of the main factors to make a decision by the government who determine its current expenditure level. In other words, the government oil revenues play a main determining for the government current expenditures at the long run. So it is necessary to change the budget policy to reduce or remove budget deficit.

\section{Conclusions}

This survey explains the roles of the tax revenue and the oil revenue to determine of the government expenditures in Iran during 1986 to 2110. This study says how government revenues changing affect on government expenditures. The results of the study show the oil revenue is one of the most important factors to determine the government current expenditure level in Iran at the long run. Therefore the results of the research can be useful for the decision makers to take a good decision in order to reduce or remove the budget deficit.

\section{References}

[1] Adnan Mazarei, (1996), The Iranian Economy under the Islamic Republic: Institutional Change and Macroeconomic Performance (1979-1990), Cambridge Journal of Economics 20: 289-314

[2] Ahmad, H., \& Millar, S. M. (2000). Crowding-out and Crowdinging Effects of the Components of Government Expenditure. Contemporary Ecnomic Policy, 18, 124-133

[3] Aisen, A., \& Hauner, D. (2008). Budget Deficit and Interest Rates. IMF Working Papers , 42, 1- 21

[4] Alberto Alesina and Allan Drazen, (1991), Why Are Stabilizations Delayed?, American Economic Review 81, 1170-88

[5] Al-Khedair, S. I. (1996). The Impact of the Budget Defecit on Key Macroeconomic variables in the Major Industrial Countries. PhD Dissertation, Florida Atlantic University

[6] Bahmani, O. M. (1999), The Federal Budget Deficits Crowd-out or Crowd-in Private Investment. Journal of Policy Modeling , 21, 633-640

[7] Barro. (1978). Comment from an Unreconstructed Ricardian. Journal of Monetary Economics , 4, 569-581

[8] Barro. (1979). On the Determination of the Public Debt. Journal of Political Economy, 87, 240- 271

[9] Blackley, P. R., (1986), Causality between revenues and expenditure and the size of the Federal Budget, Public Finance Quarterly

[10] Cebula, J. R. (1988), Federal Government Budget Deficits and Interst Rates: A brief Note. Southern Economic Journal , 55, 206210

[11] Cebula, R. (2003), Budget Deficit and Reat Interest Rates: Updated Empirical Evidence on Causality. Atlantic Economic Journal , 31 (3), 255-265

[12] David Joulfaian and Michael L. Marlow, (1991), The Relationship between On-Budget and Off-Budget Government, Economic Letters 35, 307-10

[13] Donald V. Coes, (1995), Macroeconomic Crises, Policies, and Growth in Brazil, 1964-90 (Washington, D.C.: World Bank

[14] Djavad Salehi-Isfahani, (1989), The Political Economy of Credit Subsidy in Iran, 1973-1978, International Journal of Middle East Studies 21, 359-79.

[15] Djavad Salehi-Isfahani, (1996), Government Subsidies and Demand for Petroleum Products in Iran, Research in Middle East Economics 1, 53-81 
[16] Ghali, K., \& Al-Shamsi, F. (1997). Fiscal Policy and Economic Growth: A study relating to the United Arab Emirates, Economies International , 50, 519-533

[17] Giannaros, D., \& Kolluri, B. (1989), the Impact of Budget Deficits on Real Interest Rates: An International Empirical Investigation, International Economic Journal , 3 (2), 17-25

[18] Hadi Salehi Esfahani and Hoe Jeong Kim, (2000), On Hiding and Revealing Public Debt, Department of Economics, University of Illinois at Urbana-Champaign

[19] Hakkio, C. S. (1996). The Effects of Budget Deficit Reduction on the Exchange Rate. Economic Review (Federal Reserve Bank of Kansas City), 81, 21-38

[20] Huynh, N. D. (2007). Budget Deficit and Economic Growth in Developing Countries: The case of Vietnam. Kansai Institute for Social and Economiic Research (KISER)

[21] Ibid; Vahid Nowshirvani, (1997), The Economy under the Islamic Republic, Encyclopedia Iranica, vol. 4, fasc. 2, Economy

[22] J. Edgardo Campos and Sanjay Pradhan, (1996), The Impact of Budgetary Institutions on Expenditure Outcomes," Policy Research Working Paper No. 1646 (Washington, D.C.: World Bank)

[23] Keho, Y. (2010). Budget Deficits and Economic Growth: Causality Evidence and Policy Implications for WAEMU Countries. European Journal of Economics, Finance and Administrative Sciences , 18, 99-104

[24] Lozano, I. (2008). Budget Deficit, Money Growth and Inflation: Evidence from the Colombian Case. Borradores de Economia , $537,1-24$

[25] Metin, K. (1998), The Relationship between Inflation and the Budget Deficit in Turkey. Journal of Business and Economic Statistics , 16, 412-422

[26] Misagh Parsa, ( 1989), Social Origins of the Iranian Revolution (New Brunswick, N.J.: Rutgers University Press

[27] Nelson, A. M., \& Singh, D. R. (1994). The Deficit-Growth Connection: Some Recent Evidence from Developing Countries. Economic Development and Cultrual Change , 42, 167-191

[28] Raquel Fernandez and Dani Rodrik, (1991), Resistance to Reform: Status-Quo Bias in the Presence of Individual- Specific Uncertainty, American Economic Review 81, 1146-55

[29] Sameni Keivani. Farshad et al, 2013, "The Estimation Of The Potential Capacity Of Zakah -A Case Study Of Iran”, Journal of Basic and Applied Scientific Research, text road, ISSN 2090-4304

[30] Sameni Keivani. Farshad et al, 2013, "The Creation Of bankruptcy prediction model with using Ohlson and Shirata models" Journal of Basic and Applied Scientific Research, text road, ISSN 2090-4304

[31] Sameni Keivani. Farshad et al, 2013, "The Estimation of the Underdevelopment Degree of Different Regions- A Case Study of the Cities of Guilan Province in Iran" World Applied Sciences Journal, 22 (10): 1395-1400, 2013, ISSN 1818-4952

[32] Sameni Keivani. Farshad et al, "The Historical Lack of Capital Accumulation in Iran's Agricultural Part", 11(5) IOSR Journals of Business and Management (IOSR-JBM) e-ISSN: 2278-487X, p-ISSN: 2319-7668. Volume 10, Issue 4 (May. - Jun. 2013), PP 88-90

[33] Sameni Keivani. Farshad et al, “Advantages and Barriers of E-Banking in Iran”, Nature and Science Journal 2013;11(5)

[34] Jalali, L. and Sameni Keivani. Farshad, "An Investigation of Historical Geography", 11(5) IOSR Journals of Humanities and Social Science (IOSR-JHSS) e-ISSN: 2279-0837, p-ISSN: 2279-0845. Volume 17, Issue 2 (Nov. - Dec. 2013), PP 26-30

[35] Sameni Keivani. Farshad et al, An Investigation of the Internet Effects on Business, IOSR Journals of Business and Management (IOSR-JBM) e-ISSN: 2278-487X, p-ISSN: 2319-7668. Volume 13, Issue 6 (Sep. - Oct. 2013), PP 96-99

[36] Saleh, S. A. (2003). The Budget Deficit and Economic Performance. University Wollongong Economics Working Paper Series , $12,1-55$

[37] Shojai, S. (1999). Budget Deficits and Debt: A Global Perspective (2nd Ed.). New York, USA: Praeger Publishers

[38] Sill, K. (2005), Do Budget Deficits Cause Inflation?, Business Review , 26-33

[39] Vamvoukas, G. A. (2000). Short and Long Run Effects of Budget Deficits on Interest Rates. Spoudai, 50, 58-73

[40] Vamvoukas, G., Athens, A., Vassilios, N., \& Gargalas, H. (2008). Testing Keynesian Proposition and Ricardian Equivalence. Journal of Business \& Economics Research , 6, 67-76

[41] Vit, K. (2004). The Possibilities of Budget Deficit Financing. Ministry of Finance of the Czech Republic, 44, $1-17$

[42] Von Furstenberg, George M. R, Jeffrey Green and Jin-Ho Jeong, (1986), Tax and spend or spend and tax?, Review of Economics and Statistics

[43] William Easterly, (1999), When Is Fiscal Adjustment an Illusion? , Economic Policy 14, 55-86.

[44] www.cbi.ir 